\title{
Assessment on optimization of charcoal unit for designing point of use water filter
}

\begin{abstract}
Water pollution is one of the major concerns of the world today and the demand of pure clean drinking water is increasing day by day. Water issues and problems, especially in the developing countries are more challenging. Scarcity of drinking water in certain areas, frequent discharging of untreated sewage and contamination of rivers and large dams represent few examples. In this study, we describe a simple method to prepare charcoal at home, to activate it for higher efficiency followed by design of simple charcoal cake in order to employ it as point of use water filter. Surface water as well as ground water from various locations of Kathmandu valley and Kavre district is analyzed in charcoal filter. The analysis is mainly focused on parameters like total dissolved solids, electrical conductivity, $\mathrm{pH}$, turbidity, ferrous and arsenic concentration. Three types of charcoal are employed and the results are compared. Wood charcoal shows superior performance among other charcoal precursors and is activated to enhance its performance. The results show significant reduction in total dissolved solids, electrical conductivity, and turbidity after passing through wood charcoal, activated wood charcoal and filter cake. Charcoal cake, described in this project showed around $40 \%$ reduction in ferrous ion concentration when measured using UV-Vis spectrophotometer. Moreover, such cakes can be personally carried away for e.g. during travelling and can be applied at the time of need. Further work in this project can lead to optimize the product which might gain wide popularity in many countries.
\end{abstract}

Keywords: water quality, activated charcoal, ground water, filter cake
Volume I Issue 6 - 2017

\author{
Rajendra Joshi,' Pallavi Kunwar,' Rita Bhatta,' \\ Rajan Shrestha ${ }^{3}$ \\ 'Department of Chemical Science and Engineering, Kathmandu \\ University, Nepal \\ ${ }^{2}$ Department of Environmental Science and Engineering, \\ Kathmandu University, Nepal \\ ${ }^{3}$ Department of Pharmacy, Kathmandu University, Nepal
}

Correspondence: Rajendra Joshi, Department of Chemical Science and Engineering, School of Engineering, Kathmandu University, Nepal, Tel +977 I |66 | 399, Fax +977| I 66 |443, Email rajendra.joshi@ku.edu.np

Received: July 26, 2017 | Published: November 29, 2017

\section{Introduction}

Access to clean water is a global issue and according to WHO, more than one billion people cannot access clean water. ${ }^{1}$ The situation becomes more critical in the third world countries where in some places there is severe scarcity as well as high contamination in water. In this study, Kathmandu metropolitan city $\left(27.7172^{\circ} \mathrm{N}\right.$ and $\left.85.3240^{\circ} \mathrm{E}\right)$ and Kavre district $\left(27.5259^{\circ} \mathrm{N}\right.$ and $\left.85.5612^{\circ} \mathrm{E}\right)$, Nepal were considered as the site of study. The study sites are shown in the following map (Figure 1) of Nepal $\left(28.3949^{\circ} \mathrm{N}\right.$ and $\left.84.1240^{\circ} \mathrm{E}\right)$. Because the water supply from responsible government agency is not sufficient in Kathmandu, people rely more on ground water to meet their daily needs. Ground water exhibit more salts leading to higher total dissolved solids (TDS) and also high electrical conductivity (EC) but generally do not contain bacteria. ${ }^{2}$ Further, various physicochemical parameters of water from Kathmandu valley exceed WHO and Nepal standards. ${ }^{3,4}$ There are various strategies to purify water and also to treat water. ${ }^{5,6}$ Water purification using activated charcoal is already well established method adapted in many countries for a long period in order to remove for e. g. particulate matter and chlorine from water. ${ }^{7-9}$ Further, such filters also remove objectionable taste and odor of water. However, such charcoal beds accumulate bacteria as well as organic nutrients from water thus resulting to marked growth of bacteria. ${ }^{10}$ Keeping all these issues in mind, three different types of charcoal were exploited in this study for their efficient use. Surface water as well as ground water from three various locations of Kathmandu Valley and Kavre district, Nepal was selected in this study. The aim was to make simple, cheap charcoal at home, activate it in one run and use for water purification. The physico-chemical parameters such as color, $\mathrm{pH}$, total dissolved solids (TDS), electrical conductivity (EC), and turbidity were analyzed. The primary objective was to figure out the most efficient charcoal and activate it for removing salts of ground water of Kathmandu and Kavre. After that, charcoal cake was designed and prepared. The final aim was to make a small, cheap, portable carbon filter which can be personally carried away and is applicable for point of use water filtration.

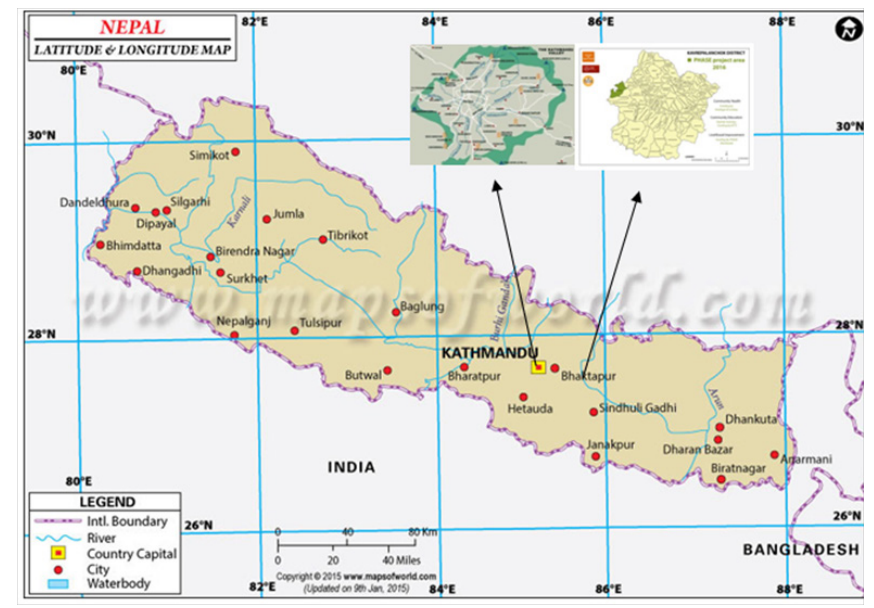

Figure I Map of Nepal showing study sites.

\section{Method}

Three types of woods (normal woods, coconut shells and corncobs) were combusted in slightly covered environment to generate charcoals. The charcoal was grinded and also activated by 
mixing with $25 \%$ calcium chloride solution. Thus prepared slurry was left for impregnation (24h).The mixture was washed several times to remove unreacted $\mathrm{CaCl}_{2}$ followed by oven drying $\left(250^{\circ} \mathrm{C}, 1 \mathrm{hr}\right)$. The obtained charcoal was tested for analyzing the water quality parameters. $\mathrm{pH}$, TDS, and EC were measured using instrument 'Consort bvba' (Parklaan 36, B-2300 Turnhout, Belgium). Charcoal cake was prepared as described here. Gelatin $(10 \mathrm{~g})$ and water $(50 \mathrm{~mL})$ were mixed to make $20 \% \mathrm{wt} / \mathrm{vol}$. It was heated at around $50^{\circ} \mathrm{C}$ until it got completely dissolved. Camphor $(5 \mathrm{~g})$ was added to make it porous. This mixture was added to activated carbon powder $(100 \mathrm{~g})$. It was mixed until the paste became thick to take a shape. The paste was molded in round form and was air dried overnight. The mold was heated slightly $\left(20^{\circ} \mathrm{C}\right)$ for $5 \mathrm{~min}$. The mold was submerged in $2.5 \%$ glutaraldehyde solution overnight to generate the strength on the cake. The final cake was washed with water, acetone $(5 \mathrm{~mL})$ was added dropwise to open more pores and again washed several times with water to make the cake free of contaminants. Concentration of ferrous test was estimated using UV-Vis spectrophotometer following standard protocol of ferrous test with 1,10-phenanthroline solution. By diluting $10 \mathrm{ppm}$ stock solution of ferrous salt; 0.2, 0.4, 0.5, 0.6 , $0.8,1,2,3,4$ and 5 ppm concentration of ferrous ion was prepared. The absorbance of each standard concentration of ferrous ion was measured at $515 \mathrm{~nm}$. A calibration curve was then plotted from the obtained data. After that, water samples under investigations were analyzed in the same UV-Vis spectrophotometer and the absorbance was noted.

\section{Results and discussion}

Three types of charcoals prepared from normal woods, coconut shells and corncobs were investigated in the beginning. Ground water samples of three different locations (Chabhil, Nilopul, Kupandole) were filtered through these charcoal filters. $\mathrm{pH}$, TDS, EC and turbidity were investigated before and after passing out through these filters. As shown in Table 1, the average value of $\mathrm{pH}$ was slightly higher after passing through these filters. TDS and EC were marginally reduced whereas turbidity was significantly decreased. Higher value of TDS and EC after passing through coconut shell could be attributed to improper washing of the charcoals. Therefore, in other studies, thorough washing was performed until the distilled water depicted almost same value before and after filtration. From these data, wood charcoal seemed relatively better in terms of purification and on the other hand, it was the easiest to prepare. Therefore, further work was mainly focused on wood charcoal. Concentration of iron is higher in the ground water of Kathmandu and also arsenic is observed in the ground water of some districts within Nepal. ${ }^{11}$ Therefore, the research was focused in removing iron and arsenic from the water. In order to study it, iron and arsenic salts were added in the distilled water and the effectiveness of the filters in removing these ions was studied.
$200 \mathrm{ppm}, 100 \mathrm{ppm}$ and $50 \mathrm{ppm}$ ferrous solution in distilled water were prepared and filtered through self-activated wood charcoal. As shown in Table 2, $200 \mathrm{ppm}$ ferrous solution in distilled water showed remarkable decrease $(27 \%$ and $29 \%)$ in TDS and EC after passing through filter. Likewise, $100 \mathrm{ppm}$ and $50 \mathrm{ppm}$ ferrous solution in distilled water also exhibited significant reduction in TDS and EC after passing through activated wood charcoal filter. The results were promising in terms of removing ferrous salt. After the iron test, the filter was further tested for arsenic removal. 5, 10 and $15 \mathrm{ppm}$ arsenic solution in distilled water were prepared and passed through the activated charcoal. The results are depicted in Table 3. As shown in Table 3, all three concentrations of arsenic were effectively reduced after passing through the filter. There was 47 to $71 \%$ reduction in TDS and 47 to $70 \%$ reduction in EC. These results are promising to employ carbon filter in third world countries like Nepal where there is more iron in ground water and also arsenic salts in some areas. Further, we verified our results by evaluating the surface water (Khar Khola river) and ground water (Kathmandu University shallow well) of Dhulikhel (Kavre). As shown in Table 4, TDS, EC and turbidity were lower after passing through self-activated charcoal. This result shows that currently used charcoal is applicable in surface water and ground water purification also. Because the results were promising in removing ions, finally, a small, cheap, portable filter cake was designed and prepared in order to employ in point of use purification. As shown in Figure 2, the size and strength is perfect to make it portable. The size of the charcoal cake was $3 \mathrm{~cm}$ thick having $6 \mathrm{~cm}$ diameters. Preliminary investigation was performed on filter cake to check its efficiency in removing ions. Surface water (Khar Khola river) and ground water (Kathmandu University shallow well) of Dhulikhel (Kavre) were passed through the filter cake and TDS, EC and turbidity were measured before and after the filtration. As shown in Table 5, there was 21 to $47 \%$ reduction in TDS, 20 to $45 \%$ reduction in EC and 75 to $90 \%$ reduction in turbidity after passing through the filter. Filter cake was further investigated for removing ferrous ions by using UV-Vis spectrophotometer. At first, the correlation between concentration and absorbance of the standard ferrous salt solution was established. As shown in Figure 3, there was a linear relationship between the concentration of the ferrous ion and the absorbance with $\mathrm{R}^{2}$ value of 0.9652 . The equation of the line from the calibration curve is $y=0.5672 x$ where $y$ is the absorbance; $x$ is the concentration of iron in ppm and 0.5672 is the slope of the line. Surface water (Khar Khola river) of Kavre was analyzed for iron concentration. Before filtration through the cake, the absorbance of the water sample was 0.047 implying the concentration to be $0.08 \mathrm{ppm}$ whereas the same sample after passing through the carbon cake resulted in absorbance 0.027 with concentration implying $0.047 \mathrm{ppm}$. Hence, it is clearly observed that the newly designed carbon cake filter reduced $>40 \%$ of ferrous ions concentration.

Table I Average values of parameters before and after passing through the filters

\begin{tabular}{lllll}
\hline Parameters & $\begin{array}{l}\text { Before } \\
\text { filtration }\end{array}$ & $\begin{array}{l}\text { Filtration through corncobs } \\
\text { charcoal }\end{array}$ & $\begin{array}{l}\text { Filtration through wood } \\
\text { charcoal }\end{array}$ & $\begin{array}{l}\text { Filtration through coconut shell } \\
\text { charcoal }\end{array}$ \\
\hline $\mathrm{PH}$ & 5.9 & 7.88 & 8.08 & 8.53 \\
$\mathrm{TDS}$ & $393 \mathrm{mg} / \mathrm{L}$ & $380 \mathrm{mg} / \mathrm{L}$ & $328 \mathrm{mg} / \mathrm{L}$ & $461 \mathrm{mg} / \mathrm{L}$ \\
$\mathrm{EC}$ & $739 \mu \mathrm{S} / \mathrm{cm}$ & $727 \mu \mathrm{S} / \mathrm{cm}$ & $615 \mu \mathrm{S} / \mathrm{cm}$ & $889 \mu \mathrm{S} / \mathrm{cm}$ \\
Turbidity & $79.6 \mathrm{FNU}$ & $43.6 \mathrm{FNU}$ & $2.8 \mathrm{FNU}$ & $47.6 \mathrm{FNU}$ \\
\hline
\end{tabular}


Table 2 TDS and EC values of 200ppm, I00ppm and 50ppm ferrous solution before and after passing through activated wood charcoal

\begin{tabular}{|c|c|c|c|c|c|c|}
\hline \multirow[t]{2}{*}{ Parameters } & \multicolumn{2}{|l|}{200 ppm } & \multicolumn{2}{|l|}{100 ppm } & \multicolumn{2}{|l|}{50 ppm } \\
\hline & Before filtration & After filtration & Before filtration & After filtration & Before filtration & After filtration \\
\hline TDS & 378 mg/L & $275 \mathrm{mg} / \mathrm{L}$ & $238 \mathrm{mg} / \mathrm{L}$ & 166 mg/L & 107 mg/L & $94 \mathrm{mg} / \mathrm{L}$ \\
\hline EC & $728 \mu \mathrm{S} / \mathrm{cm}$ & $517 \mu S / c m$ & $428 \mu \mathrm{S} / \mathrm{cm}$ & $420 \mu \mathrm{S} / \mathrm{cm}$ & $202 \mu \mathrm{S} / \mathrm{cm}$ & $179 \mu \mathrm{S} / \mathrm{cm}$ \\
\hline
\end{tabular}

Table 3 TDS and EC values of I 5 ppm, I0ppm and 5ppm arsenic solution before and after passing through activated wood charcoal

\begin{tabular}{|c|c|c|c|c|c|c|}
\hline \multirow[t]{2}{*}{ Parameters } & \multicolumn{2}{|l|}{ I5 ppm } & \multicolumn{2}{|l|}{10 ppm } & \multicolumn{2}{|l|}{5 ppm } \\
\hline & Before filtration & After filtration & Before filtration & After filtration & Before filtration & After filtration \\
\hline TDS & $1.89 \mathrm{~g} / \mathrm{L}$ & $934 \mathrm{mg} / \mathrm{L}$ & $1.14 \mathrm{~g} / \mathrm{L}$ & $607 \mathrm{mg} / \mathrm{L}$ & $616 \mathrm{mg} / \mathrm{L}$ & $181 \mathrm{mg} / \mathrm{L}$ \\
\hline EC & $3.51 \mathrm{mS} / \mathrm{cm}$ & I $752 \mu S / c m$ & $2.13 \mathrm{mS} / \mathrm{cm}$ & 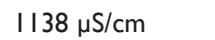 & I I $46 \mu \mathrm{S} / \mathrm{cm}$ & $34 \mathrm{I} \mu \mathrm{S} / \mathrm{cm}$ \\
\hline
\end{tabular}

Table 4 Surface and ground water purification by self-activated charcoal

\begin{tabular}{lllll}
\hline Parameters & Surface water & & Ground water & \\
& Before filtration & After filtration & Before filtration & After filtration \\
\hline TDS & $2.47 \mathrm{~g} / \mathrm{L}$ & $1.11 \mathrm{~g} / \mathrm{L}$ & $380 \mathrm{mg} / \mathrm{L}$ & $259 \mathrm{mg} / \mathrm{L}$ \\
EC & $4.37 \mathrm{mS} / \mathrm{cm}$ & $2.09 \mathrm{mS} / \mathrm{cm}$ & $727 \mu \mathrm{S} / \mathrm{cm}$ & $487 \mu \mathrm{S} / \mathrm{cm}$ \\
Turbidity & $155 \mathrm{FNU}$ & $2.5 \mathrm{FNU}$ & $45 \mathrm{FNU}$ & $8 \mathrm{FNU}$ \\
\hline
\end{tabular}

Table 5 Surface and ground water purification by filter cake

\begin{tabular}{lllll}
\hline Parameters & Surface water & & Ground water & \\
& Before filtration & After filtration & Before filtration & After filtration \\
\hline TDS & $2.47 \mathrm{~g} / \mathrm{L}$ & $1.30 \mathrm{~g} / \mathrm{L}$ & $380 \mathrm{mg} / \mathrm{L}$ & $300 \mathrm{mg} / \mathrm{L}$ \\
EC & $4.37 \mathrm{mS} / \mathrm{cm}$ & $2.40 \mathrm{mS} / \mathrm{cm}$ & $727 \mu \mathrm{S} / \mathrm{cm}$ & $580 \mu \mathrm{\mu S} / \mathrm{cm}$ \\
Turbidity & $155 \mathrm{FNU}$ & $14 \mathrm{FNU}$ & $45 \mathrm{FNU}$ & $\mathrm{II} \mathrm{FNU}$ \\
\hline
\end{tabular}

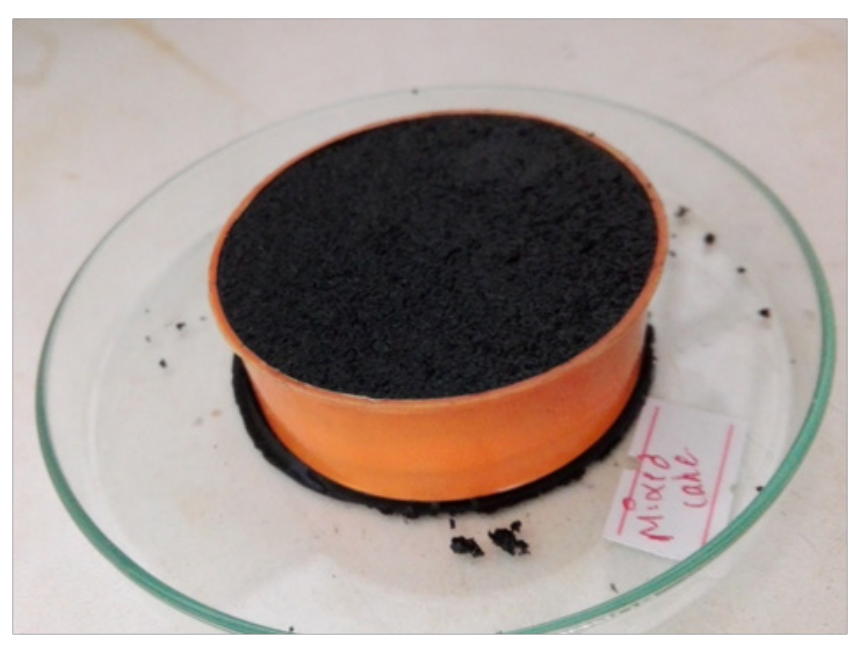

Figure 2 Filter cake prepared from activated charcoal.

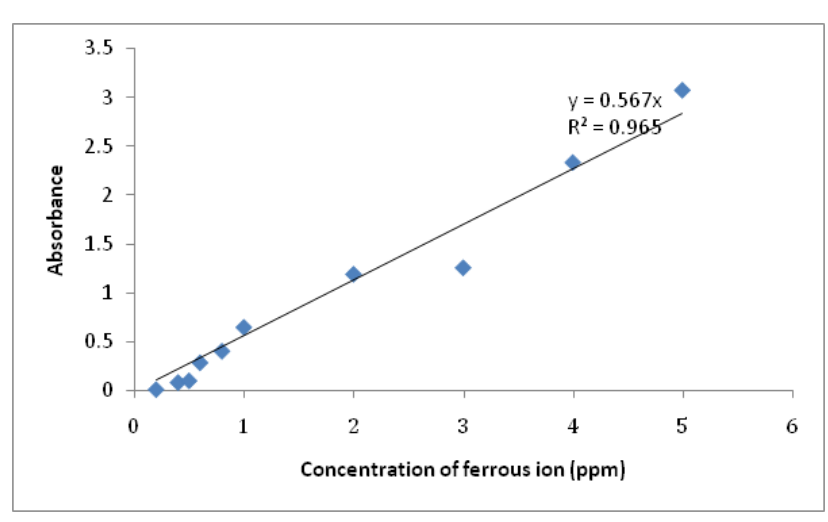

Figure 3 Calibration curve of standard ferrous ion solution.

\section{Conclusion}

Three different types of charcoal were prepared and tested their 
efficiency in enhancing the water quality. The results showed that self-activated wood charcoal is relatively better in removing ions than simple wood charcoal. The charcoal filter decreased TDS, EC and turbidity of surface water as well as ground water collected from various locations of Kathmandu valley and Kavre district, Nepal. After filtering iron solution (200, 100 and $50 \mathrm{ppm})$, there was 12 to $30 \%$ reduction in TDS and 2 to $29 \%$ decrease in EC. Also, arsenic solution $(15,10$ and $5 \mathrm{ppm})$ exhibited 47 to $71 \%$ reduction in TDS and 47 to $70 \%$ reduction in EC. Turbidity was decreased up to $98 \%$. Finally a small, portable, robust charcoal cake was designed and prepared and its efficiency in removing ions was investigated. The filter cake reduced ferrous ion concentration $(>40 \%)$ as confirmed by UV-Vis spectrophotometer. Therefore, it can be concluded that such charcoal cakes can be of prime use during for e. g. travelling in many parts of the world. Further work in this project will help to optimize the product better for pollutant removal. In future, paper impregnated with silver nanoparticles will be used on the surface of the filter cake to inactivate bacteria.

\section{Acknowledgments}

None.

\section{Conflict of interest}

Authors declare there is no conflict of interest in publishing the article.

\section{References}

1. World Health Organization. Water for Life: Making it Happen. World Health Organization (WHO), Switzerland; 2005. p. 1-44.
2. Pant BR. Ground water quality in the Kathmandu valley of Nepal. Environ Monit and Assess. 2011;178(1-4):477-485.

3. Warner NR, Levy J, Harpp K, et al. Drinking water quality in Nepal's Kathmandu Valley: a survey and assessment of selected controlling site characteristics. Hydrogeology Journal. 2008;16(2):321-334.

4. Koju NK, Prasai T, Shrestha SM, et al. Drinking water quality of Kathmandu valley. Nepal Journal of Science and Technology. 2014;15(1):115-120.

5. Bhatta R, Kayastha, R, Subedi DP, et al. Treatment of wastewater by ozone produced in dielectric barrier discharge. Journal of Chemistry. 2015:1-6.

6. Comninellis C. Electrocatalysis in the electrochemical conversion/ combustion of organic pollutants for waste water treatment. Electrochimica Acta. 1994;39(11-12):1857-1862.

7. Mizuta K, Matsumoto T, Hatate Y, et al. Removal of nitrate-nitrogen from drinking water using bamboo powder charcoal. Bioresource Technology. 2004;95(3):255-257.

8. Mohan SV, Karthikeyan J. Removal of lignin and tannin colour from aqueous solution by adsorption onto activated charcoal. Environmental Pollution. 1997;97(1-2):183-187.

9. Wang FY, Wang H, Ma JW. Adsorption of cadmium (II) ions from aqueous solution by a new low-cost adsorbent-Bamboo charcoal. Journal of Hazardous Materials. 2010;177(1-3):300-306.

10. Wallis C, Stagg CH, Melnick JL. The hazards of incorporating charcoal filters into domestic water systems. Water Research. 1974;8(2):111-113.

11. Shrestha RR, Shrestha MP, Upadhyay NP, et al. Groundwater arsenic contamination, its health impact and mitigation program in Nepal. Journal of Environmental Science and Health, Part A. 2003;38(1):185-200. 